\title{
Europe breaks ranks over fusion project site
}

\section{Declan Butler, Paris}

The multibillion-dollar ITER fusion reactor was always intended to be an international collaboration, and was billed as a model for 'big science' projects. But this week, the model looks in deep trouble.

On 26 November, the European Union (EU) broke ranks with the site selection process, and announced that if agreement isn't reached quickly, it will go it alone to build the reactor in Europe.

ITER aims to prove the principle of generating energy from fusion, by confining a ring of plasma with a magnetic field in a doughnut-shaped vessel and heating it to several million degrees kelvin. But the six-strong collaboration has split over the siting of the facility: China and Russia back the EU's site in Cadarache, France, whereas the United States and South Korea favour Japan's rival site at Rokkasho.

At a meeting in Brussels, research and industry ministers from the EU's 25 member states followed through on a threat that they first aired in September. They authorized the European Commission, the EU's executive arm, to abandon the multilateral site selection process if necessary and build ITER in France, with as many outside partners as it can muster.

EU ministers insist that this option will be a last resort. The Japanese government has yet to respond, but fusion officials there reacted angrily. Satoru Ohtake, director of fusion energy at Japan's science ministry, says the EU move jeopardizes not just ITER but also the ground rules needed for future international collaborations. "By pursuing their own desires, they will be the ones that break international trust," says Ohtake. "This is divisive; it is not acceptable to us."

Commission officials counter that the stalled talks needed shock therapy and that the situation was "in complete deadlock". Political realities make site selection the inevitable crux of any international collaboration, adds one official, and "unless your project is in space, you will have always this problem of choosing the site".

Europe's most recent offer to Japan, in return for agreeing to the Cadarache site, includes a fusion package that would compensate the country and include support for a major upgrade to its JT60 fusion reactor. Ohtake claims that Japan has offered Europe similar concessions.

Neither offer prevailed, however, at the latest meeting of negotiators on 9 November in Vienna (see Nature 432, 262; 2004). Japan's position is that both parties should temporarily put aside the siting issue, says Ohtake, and discuss the "role of host and non-host parties".

Europe's brinkmanship seems partly based on the reckoning that only one ITER will ever be built, and if it can force the deadlock with firm support for a French site, then Japan and the United States will eventually join the only show in town.

This scenario is credible, says Stephen Dean, head of Fusion Power Associates, a Washingtonbased fusion advocacy group. "I think the EU could get together a package that would work," he says.

France has already offered to double its support for ITER to $\$ 1.12$ billion, or $20 \%$ of the total bill, and the rest of Europe has committed another $40 \%$. Even if Japan and the United States pulled out, Europe could conceivably make up the shortfall from Russia, China and other partners.

But some European fusion scientists fear that the EU has overplayed its hand - and underestimated Japanese determination to host ITER. "The European Commission badly misread Japan's negotiating positions; it has been convinced that Japan would budge," says one European scientist close to the negotiations. The big unknown, he says, is whether Japan will call Europe's bluff, and announce that it, too, intends to go it alone. Additional reporting by Geoff Brumfiel in Washington.

\section{Scientists decry 'spy' verdict for Russian physicist}

\section{Bryon MacWilliams, Moscow}

A Russian physicist has been sentenced to 14 years in prison after a retrial found him guilty of passing classified information to China. The verdict has been derided by scientists and human-rights observers.

Valentin Danilov admitted selling aerospace technology to a Chinese company in 1999, when he was head of the Institute of Thermodynamics at Krasnoyarsk State Technical University in Siberia.

In 2001, he was arrested by the Federal Security Service (FSB), who said his device to measure the effects of electromagnetic waves on satellites could help China to develop weapons that might threaten Russia.

But Danilov, with the public backing of prominent members of the Russian Academy of Sciences, countered that the technology was declassified in 1992 and that details of it had, in fact, been published in scientific journals. At least one of these publications is still openly available today.

The FSB has accused several scientists and environmentalists of espionage in recent years - something that humanrights groups refer to as "spy mania". But last year, in a startling setback for the agency, a jury sided with Danilov and acquitted him of all charges.

Prosecutors successfully appealed the verdict on procedural grounds and won a second trial. During this one, jurors were permitted to decide only whether Danilov had provided the information, and not whether it constituted spying. That decision was left to Judge Andrei Afanasyev of the Krasnoyarsk Regional Court, who ruled that the data were indeed secret.

The 24 November verdict was questioned by Eduard Kruglyakov, deputy head of the Budker Institute of Nuclear Physics in Novosibirsk, who said that the judge had refused to consider written testimony from Russian physicists in relevant subdisciplines.

Afanasyev also found Danilov guilty of embezzling 466,000 rubles $(\$ 16,500)$ - the first payment by the Chinese company. During the retrial he unexpectedly jailed Danilov, who had been free, after prosecutors accused the physicist of "criminal activity" for giving an interview to a US newspaper, the Los Angeles Times.

Danilov's lawyer, Yelena Yevmenova, says she will appeal the sentence in the Russian Supreme Court, as well as the European Court of Human Rights. 